\title{
Behaviors of Professional Athletes in Terms of the Big Five Model Due to the Type of Contact of the Sport Discipline
}

\author{
Pawel Piepiora \\ University School of Physical Education in Wrocław, Poland, pawel.piepiora@awf.wroc.pl
}

\begin{abstract}
Sports disciplines can be divided due to the type of contact allowed with the opponent. We distinguish disciplines with direct and indirect contact as well as non-contact disciplines. The intention of this study was to check if the behavior of professional athletes is determined by the type of contact of sports disciplines. 180 competitive athletes from six sport disciplines, i.e. luge, tennis, wrestling, team mountaineering, volleyball and rugby, were purposefully selected for the study. The research method used was the NEO-FFI Personality Inventory. It was shown that specific samples - lugers, team mountaineers and rugbists are characterized by low neuroticism in relation to tennis players, wrestlers and volleyball players. Athletes of non-contact disciplines stand out by low neuroticism in relation athletes of indirect and direct contact disciplines. Team athletes are distinguished by low neuroticism in relation to individual athletes. On this basis, the following conclusions were made. The behavior of athletes depends on the type of contact of the sport discipline. Behavioral profiles are specific to the requirements of a given sport discipline and are consistent with the average profile of behavior of all athletes, characterized by high conscientiousness and extraversion, average openness to experience and agreeableness. The indicator differentiating the behavior of athletes due to the type of contact of the sport discipline is neuroticism.
\end{abstract}

KEYWORDS: behaviours, sport psychology, personality, NEO-FFI, type of contact

\section{Introduction}

The behavior of the athlete is one of the most important elements of knowledge for the trainer. In sports competition, who wins and who loses decide the physical and mental skills of the player. But in the fight for medal positions, especially when athletes are on the same level, the player's mind determines the winning first. The one who will be more mentally resistant and will show greater will win competition. That is why mental training of the player is so important in the modern sport. Such training prepares the athlete for hard moments in sports competition and allows to predict the behavior of athletes in difficult situations.

Personality psychology is inseparably associated with explaining human behavior, hence personality measurements are used as a criterion for behavior assessment. Often, the NEO-FFI personality inventory is used for this purpose (Wiggins, 1996). It is useful in this case due to the fact that it allows you to study certain patterns in behavior exhibited over a longer period of time. Personality traits describe relatively constant dispositions, hence the search for their manifestations in repetitive patterns is more justified than in individual behaviors - these are dependent on situational factors. The NEO-FFI personality measurement tool explains behaviors that are important from a social and cultural point of view, which are usually dependent on several personality traits in parallel (Buss and Craik, 1983; Bardi and Schwartz, 2003; Paunonen, 2003; Grucza and Goldberg, 2007; John et al., 2008; Hirsh et al., 2009; Agnew et al., 2010).

From previous studies in the field of sport psychology, it appears that people who are physically active are different from those who do not exercise by high conscientiousness. In contrast, athletes (rival) from physically active people are distinguished by high extraversion. And athletes who win (champions) from the rest of the competitors are distinguished by a low marker of neuroticism (Piedmont et al., 1999; Backmand et al., 2003; McKelvie et al., 2003; Kajtna et al., 2004; Zdebski and Blecharz, 2004; Blecharz and Siekańska, 2005; Ekinci and Hosany, 2006; Shipley et al., 2007; Soto et al., 2008; Anghel et al., 2009; Hill et al., 2010; Shrivastaval et al., 2010; Allen et al., 2011; Fuller, 2011; Ilyasi and Salehian, 2011; Tok, 2011; Binboga et al., 2012; Tolea et al., 2012; Allen et al., 2013; Boostani et al., 2013; Mirzaei et al., 2013; Nielsen, 2013; Terracciano et al., 2013; Tomczak et al., 2013; Allen and Laborde, 2014; Piepiora, 2015; Piepiora 
and Piepiora, 2015; Piepiora and Witkowski, 2018; Piepiora et al., 2015, 2016a, 2016b, 2017a, 2017b, 2017c, 2017d, 2017e, 2018a, 2018b, 2019a, 2019b, 2019c, 2019d; Witkowski et al., 2018).

In the current research, it is not specified what model of behavior of athletes is characteristic of sports disciplines due to the type of contact with the opponent. In connection with the above, an attempt was made to check professional behavior profiles of athletes in terms of the "Big Five" personality model due to the type of contact with the opponent. Namely, athletes should be characterized by different personality profiles related to their behavior, in accordance with the assumption that it is the contact type of sport discipline that determines the behavior of athletes. The purpose of this study was to verify this hypothesis.

\section{Methods}

\section{Participants}

180 competitive athletes (men, $\mathrm{N}=180$ ) from six sport disciplines were selected for the study. Two selection criteria were adopted. The first criterion was the type of contact between the sport discipline: the discipline with direct contact with the opponent, the discipline with indirect contact with the opponent, and the non-contact discipline. The second criterion was the nature of the sport discipline individual or team. The test samples were as follows:

- Lugers ( $\mathrm{n}=30$, individual non-contact discipline);

- Tennis players ( $\mathrm{n}=30$, individual discipline with indirect contact);

- Wrestlers $(\mathrm{n}=30$, individual discipline with direct contact);

- Team mountaineers ( $\mathrm{n}=30$, team non-contact discipline);

- Volleyball players ( $\mathrm{n}=30$, team discipline with indirect contact);

- Rugby players $(n=30$, team discipline with direct contact).

All respondents are or have been Polish representatives at international competitions. Their age varied between 20 and 29 years of age. The subjects were selected purposefully for the samples. The inclusion criterion was: many years of sports experience; license for one of six established sports disciplines; impeccable trainer; documented sports achievements at various levels of competition (national, continental, global). The exclusion criterion was: ethical or unsportsmanlike lifestyle; no recommendation from the trainer. All participants voluntarily agreed to participate in the research.

\section{Measures}

The NEO-FFi Personality Inventory was used as a research method. It is a five-factor personality model - a personality model also called the "Big Five" constructed by P. Costa and R. McCraewhich is a continuation of the Catell and Allport theories (Allport and Odbert, 1936; Cattell, 1946, 1966). The Big Five was created on the basis of a lexical analysis of free behavior descriptions, which allowed to distinguish five superfactors, which are the basic personality traits. The Big Five scales allow a full description of the research object's behavior.

These are the following dimensions: openness to experience (positive evaluation of life experiences, tolerance for new things and cognitive curiosity), conscientiousness (organization, perseverance and motivation of the individual in goal-oriented activities), extraversion (quality and quantity of social interactions and the level of activity, energy and the ability to experience positive emotions, agreeableness (attitudes towards other people manifested in altruism and antagonism) and neuroticism (tendency to experience negative emotions, i.e. fear, confusion, anger, guilt and vulnerability to psychological stress), described in the high-low scale. The acronym OCEAN is also used to name supercells. On the basis of this theory, the NEO-FFI personality inventory was created to measure the above features. It is accepted that the above factors are independent of race, culture and gender. They are characterized by a high level of inheritance. They are immutable and affect the level of adaptation of the individual to the environment (McCrae and Costa, 2003; Costa and McCrae, 2007). 


\section{Design and Procedures}

The research was carried out by the author of the article in 2017-2018 during camps and sport camps in Poland. Respondents to completing the NEO-FFI questionnaire had one hour. The tests were approved by the local ethics committee.

\section{Statistical Analysis}

One-way analysis of variance and post-hoc tests as basic statistical methods were used. The analysis of the tests was carried out using the Statiscica 13.1 package

\section{Results}

The average results obtained are summarized in Table 1 and illustrated in Diagram 1. The power of statistically significant differences between athletes in the NEO-FFi scales is presented in Tables 2 . The results show that the behavior profiles of athletes from particular disciplines are different, which proves that this part of the verified hypothesis is true. In addition, the ANOVA analysis results in raw results for homogeneity within the extraversion features, and in the neuroticism scale for lack thereof, except for volleyball players in relation to ground tennis players and the level of lugers tendencies in relation to team climbers and rugbists. In addition, single statistically significant differences occurred on the scale of openness to experience, conscientiousness and agreeableness. After converting the results into sten (a measure in psychology), lugers, team mountaineers and rugbists are characterized by high conscientiousness and extroversion, average openness to experience and agreeableness, and low neuroticism. However, tennis players, wrestlers and volleyball players are characterized by high conscientiousness and extraversion and average openness to experience, agreeableness and neuroticism. The neuroticism was the differentiating scale.

Table 1. A comparison of the mean of the examined sports groups

Table 1

Mean SD, Each Group n=30

\begin{tabular}{ccccccc} 
NEO-FFI VARIABLE & LUGERS & $\begin{array}{c}\text { TENNIS } \\
\text { PLAYERS }\end{array}$ & WRESTLERS & $\begin{array}{c}\text { TEAM } \\
\text { MOUNTAINEERS }\end{array}$ & $\begin{array}{c}\text { VOLLEYBALL } \\
\text { PLAYERS }\end{array}$ & $\begin{array}{c}\text { RUGBY } \\
\text { PLAYERS }\end{array}$ \\
\hline OPENNESS TO & 25,96 & 28,03 & 26,06 & 31,36 & 27,03 & 24,06 \\
EXPERIENCE & & & & & & 32,76 \\
CONSCIENTIOUSNESS & 36,06 & 34,66 & 32,96 & 37,5 & 35,76 \\
EXTRAVERSION & 33,16 & 31,2 & 32,3 & 33,03 & 33,3 & 32,83 \\
AGREEABLENESS & 29,66 & 29 & 27,26 & 29,3 & 25,16 & 28,1 \\
NEUROTICISM & 9,33 & 15,1 & 17,53 & 7,4 & 13,9 & 11,23
\end{tabular}

Table 2. Specification of the power of statistically significant differences between the studied group

Table 2

Probability of post hoc test (value $p$ ), each group $n=30$

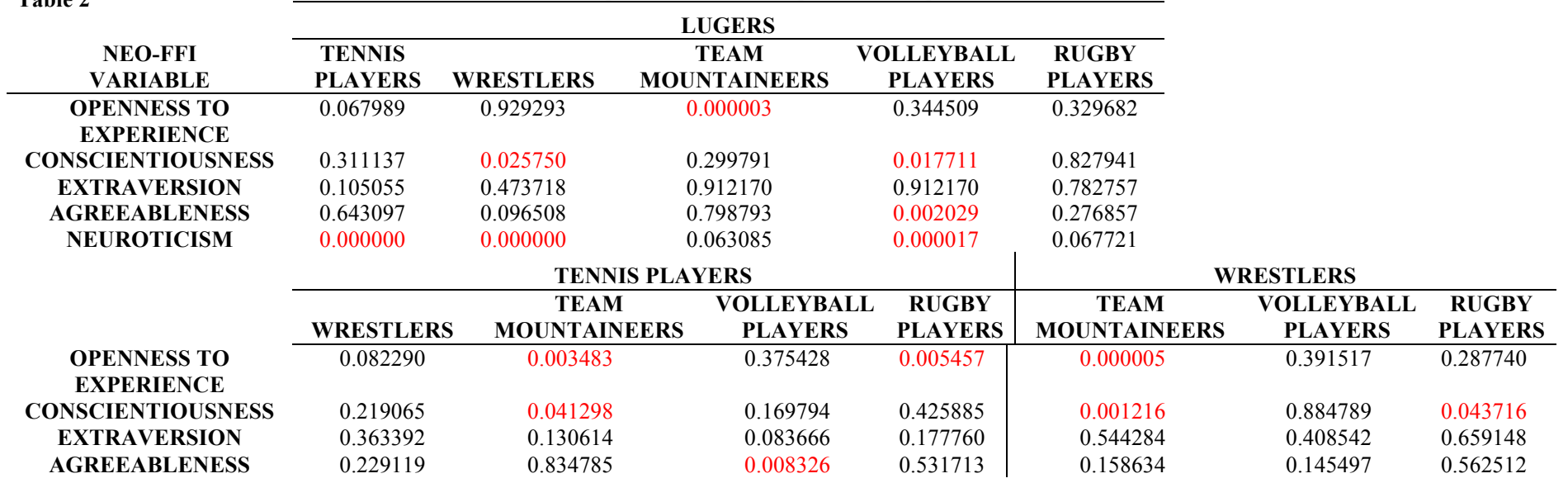




\begin{tabular}{|c|c|c|c|c|c|c|c|}
\hline \multirow[t]{3}{*}{ NEUROTICISM } & 0.019672 & 0.000000 & 0.247216 & 0.000249 & 0.000000 & 0.000560 & 0.000000 \\
\hline & \multicolumn{2}{|c|}{$\begin{array}{c}\text { TEAM } \\
\text { MOUNTAINEERS }\end{array}$} & $\begin{array}{l}\text { VOLLEYBALL } \\
\text { PLAYERS }\end{array}$ & & & & \\
\hline & $\begin{array}{c}\text { VOLLEYBALL } \\
\text { PLAYERS } \\
\end{array}$ & $\begin{array}{c}\text { RUGBY } \\
\text { PLAYERS } \\
\end{array}$ & $\begin{array}{c}\text { RUGBY } \\
\text { PLAYERS } \\
\end{array}$ & & & & \\
\hline $\begin{array}{l}\text { OPENNESS TO } \\
\text { EXPERIENCE }\end{array}$ & 0.000165 & 0.000000 & 0.055814 & & & & \\
\hline CONSCIENTIOUSNESS & 0.000743 & 0.210203 & 0.030850 & & & & \\
\hline EXTRAVERSION & 0.825411 & 0.868591 & 0.699512 & & & & \\
\hline AGREEABLENESS & 0.004505 & 0.404566 & 0.042621 & & & & \\
\hline NEUROTICISM & 0.000000 & 0.000280 & 0.010703 & & & & \\
\hline
\end{tabular}

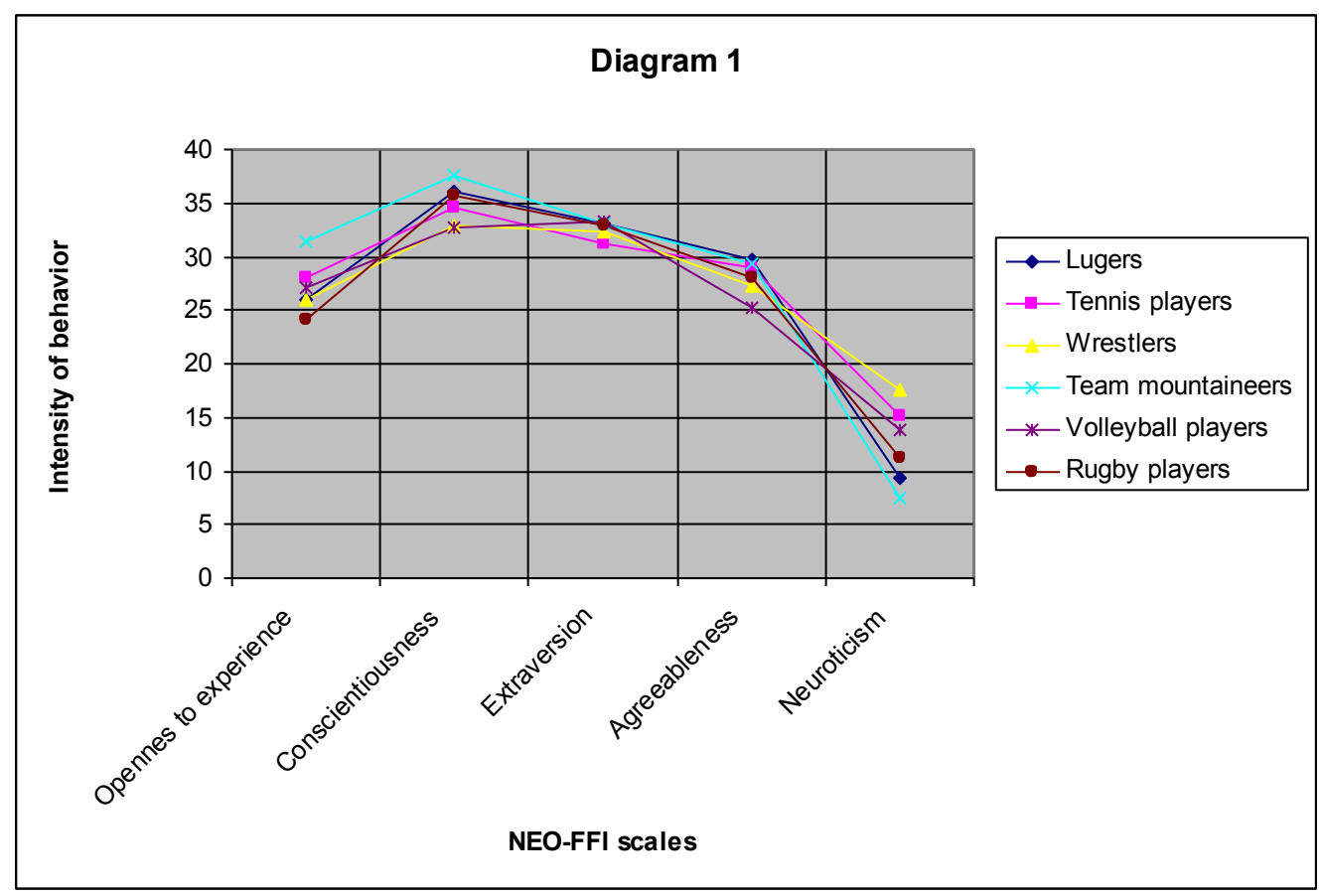

Diagram 1. Summarised data of the examined sports groups

Next, the differences between athletes were checked strictly due to the contact type of the sport discipline. For this purpose, the direct contact disciplines (Wrestling and Rugby), the indirect contact disciplines (Tennis and Volleyball) and the non-contact disciplines (Luge and Team Mountaineering) were juxtaposed together. The average values are summarized in Table 3 and illustrated in Diagram 2. In the raw results, statistically significant differences were found in the scales of openness to experience, conscientiousness, agreeableness and neuroticism. On the sten scale, athletes of non-contact disciplines are characterized by high conscientiousness and extraversion, average openness to experience and agreeableness, and low neuroticism. Whereas athletes of indirect and direct contact disciplines are characterized by high conscientiousness and extraversion, as well as average openness to experience, agreeableness and neuroticism. Again, the differentiating scale was neuroticism.

Table 3. A comparison of means and power statistically significant differences due to the type of contact of a sports discipline

\begin{tabular}{ccc|cc|cc} 
Table 3 & \multicolumn{2}{c|}{$\begin{array}{c}\text { NON-CONTACT } \\
\text { DISCIPLINE }(\mathbf{n = 6 0})\end{array}$} & \multicolumn{2}{c|}{$\begin{array}{c}\text { INDIRECT CONTACT } \\
\text { DISCIPLINE }(\mathbf{n = 6 0})\end{array}$} & \multicolumn{2}{c}{$\begin{array}{c}\text { DIRECT CONTACT } \\
\text { DISCIPLINE }(\mathbf{n = 6 0})\end{array}$} \\
\cline { 2 - 8 } NEO-FFI VARIABLE & Mean SD & $\mathbf{p}$ & Mean SD & $\mathbf{p}$ & Mean SD & $\mathbf{p}$ \\
\hline OPENNESS TO & & & & & & \\
EXPERIENCE & 28.66 & 0.180863 & 27.53 & 0.015270 & 25.46 & 0.000204 \\
CONSCIENTIOUSNESS & 36.78 & 0.002175 & 33.71 & 0.510521 & 34.36 & 0.015199 \\
EXTRAVERSION & 33.1 & 0.320986 & 32.25 & 0.711252 & 32.56 & 0.533133
\end{tabular}




\begin{tabular}{ccc|cc|cc} 
AGREEABLENESS & 29.48 & 0.020741 & 27.08 & 0.560369 & 27.68 & 0.081818 \\
NEUROTICISM & 8.36 & 0.000000 & 14.5 & 0.885265 & 14.38 & 0.000000
\end{tabular}

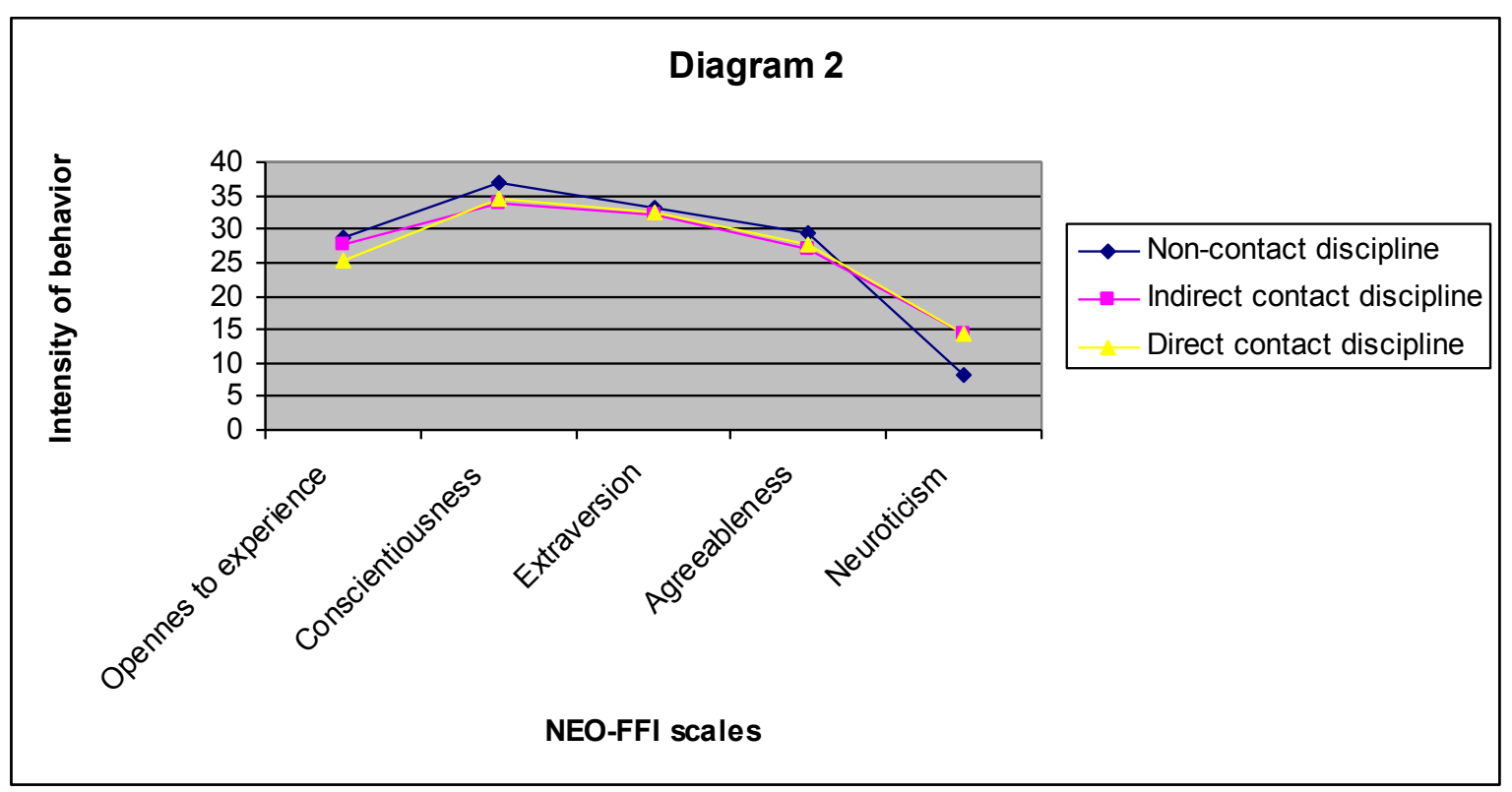

Diagram 2. Summarised data of all athletes due to the contact type of the sport discipline

Next, statistically significant differences between athletes were checked due to the nature of sports disciplines. Individual disciplines (Luge, Tennis, Wrestling) were combined with team disciplines (Team Mountaineering, Volleyball, Rugby). The average results are shown in Table 4 and Diagram 3 . The raw results show a statistically significant difference only on the neuroticism scale. On the sten scale, the same dependence occurred. Athletes are characterized by high conscientiousness and extraversion, average openness to experience and agreeableness. But team athletes are distinguished by low neuroticism in relation to individual athletes (average neuroticism). For the third time, neuroticism is the differentiating scale.

Table 4. A comparison of means and power statistically significant differences due to the character of a sports discipline

\begin{tabular}{lccc}
\multicolumn{1}{c}{ Table 4} & \multicolumn{2}{c}{ Mean SD } & p \\
\cline { 2 - 3 } \multicolumn{1}{c}{ NEO-FFI VARIABLE } & INDIVIDUAL DISCIPLINES (n=90) & TEAM DISCIPLINES (n=90) & \\
\hline OPENNESS TO & & & 0.135071 \\
EXPERIENCE & 26.68 & 27.75 & 0.346843 \\
CONSCIENTIOUSNESS & 34.56 & 35.34 & 0.231820 \\
EXTRAVERSION & 32.22 & 33.05 & 0.186914 \\
AGREEABLENESS & 28.64 & 27.52 & 0.000042 \\
NEUROTICISM & 13.98 & 10.84 &
\end{tabular}




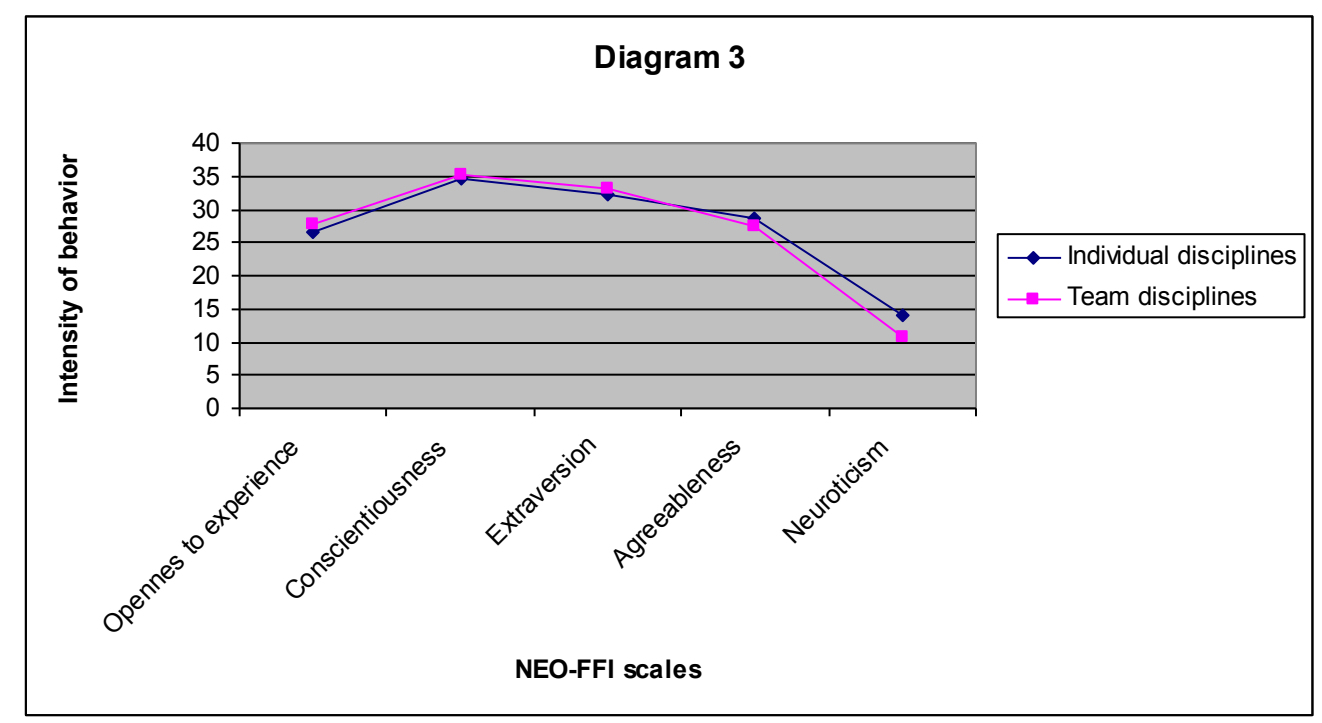

Diagram 3. Summarised data of all athletes due to the character of the sport discipline

\section{Discussion}

The obtained results show that the type of contact of the sport discipline determines the behavior of athletes. The variety of sports disciplines depending on the type of contact indicates their individual character. Therefore, the behavioral profiles included in the NEO-FFI model are specific to the requirements of a given discipline. The results clearly show that the behavior of athletes varies depending on the type of contact of the sport discipline.

Considering all the samples, it was noticed that the indicator differentiating the behavior of athletes due to the type of contact of the sport discipline is neuroticism. This is a tendency to experience negative emotional states. Neurotic people are more prone to showing fear, anger, jealousy, sadness and guilt. They react more severely to everyday stress and deal with it less well. They are often self-conscious and shy. Neuroticism is also a risk factor for phobias, mood disorders, panic disorder and other anxiety disorders, formerly referred to as neuroses. The opposite of neuroticism is emotional stability. It is characterized by a milder reaction to stress, calmness and a lower tendency to being tense or aroused. On the other hand, although people who are emotionally stable experience less difficult feelings, they do not necessarily have to experience more positive feelings. A high rate of experiencing pleasant feelings is associated with extraversion. And so, for example, neurotic extroverts - tennis players, wrestlers and volleyball players - experience a lot of both pleasant and unpleasant feelings, perceived as mood swings. On the other hand, people with low levels of neuroticism and high extraversion - lugers, team mountaineers and rugbists - are usually more joyful and content with life.

Behavior is shaped both as a result of innate properties and external factors. Different authors, depending on the adopted concepts, assign a decisive role to behavior. Behavior is a specific, multidimensional personality structure characteristic of a given person. The relatively long-lasting qualities that make up the personality influence each other. Therefore, they should be treated together, and their essence comes down to the description of the individual's behavior. We learn to a certain extent by observing important persons behaving in such a way. In this case, the type of contact and the nature of the sport discipline turned out to be crucial. In non-contact disciplines: individual - luger; team - team mountaineering; low level of neuroticism results from the lack of contact with the opponent. In these disciplines, competition is about fighting against time, with your own limitations, with yourself. Whereas in disciplines with indirect contact: individual - tennis; team - volleyball; the average rate of neuroticism results from the emotional tension caused by eye contact with the opponent and the lack of direct contact. In this case, the main measure of players' skills is the ball - the way it is accepted and / or played. The sense of self-efficacy largely depends on the subject of the game. On the other hand, disciplines with direct contact: individual - wrestling; 
team - rugby; the measure of neuroticism depends on the nature of the sport discipline. And so in wrestling is direct contact with the opponent - one on one - the competitor is facing the opponent and his own weaknesses. But in rugby there is direct contact with one or several opponents. In Rugby, the emotional tension is distributed to the entire team, and one player maintains it in wrestling. The perceived level of stress, anxiety and anger is therefore dependent on the number or absence of the game's companions.

\section{Conclusions}

The behavior of athletes depends on the type of contact of the sport discipline. Behavioral profiles are specific to the requirements of a given sport discipline and are consistent with the average profile of behavior of all athletes, characterized by high conscientiousness and extraversion, average openness to experience and agreeableness. The indicator differentiating the behavior of athletes due to the type of contact of the sport discipline is neuroticism.

\section{References}

Agnew, CR, Carlston DE, Graziano WG, Kelly JR. 2010. Then a miracle occurs: Focusing on behavior in social psychological theory and research. New York: Oxford University Press, 205-226.

Allen, MS, Greenlees I, Jones M. 2011. "An investigation of the five-factor model of personality and coping behaviour in sport." Journal of Sport Sciences 29: 841-850.

Allen, MS, Greenlees I, Jones M. 2013. "Personality in sport: a comprehensive review." International Review of Sport and Exercise Psychology 6: 184-208.

Allen, MS, Laborde S. 2014. "The role of personality in sport and physical activity." Current directions in psychological science 23: 460-465.

Allport, GW, Odbert HS. 1936. “Trait names: A psycho-lexical study.” Psychological Monographs 47: 1-171.

Anghel, A, Banica I, Ionescu S. 2009. "Personality features of elite athletes considering the criterion of the sport practiced." Sport Science Review 1: 5-6.

Backmand, H, Kapiro J, Kujala U, Sarna S. 2003. "Personality and mood of former elite athletes: a descriptive study." Internalional Journal of Sports Medicine 22: 215-221.

Bardi, A, Schwartz SH. 2003. "Values and behavior: Strength and structure of relations." Personality and Social Psychology Bulletin 29: 1207-1220.

Binboga, E, Guven S, Catikkas F, Bayazit O, Tok S. 2012. "Psychophysiological responses to competition and the Big Five personality traits." Journal of Human Kinetics 33: 187-194.

Blecharz, J, Siekańska M. 2005. "Physical trauma and mental condition of the athlete." Medicina Sportiva 9 (3): 1-6.

Boostani, MH, Boostani MA, Rezaei AM. 2013. "Sport psychology in professional karate athletes: give psychological guidelines in order to improve their act in the competitions." Annals of Biological Research 4 (1): 48-52.

Buss, D, Craik KH. 1983. “The act frequency approach to personality.” Psychological Review 90: 105-126.

Cattell, RB. 1946. The description and measurement of personality. New York: World Book.

Cattell, RB. 1966. "The scree test for the number of factors." Multivariete Behavioral Research 1: 245-276.

Costa, Jr. P, McCrae R. 2007. Personality inventory Five Factor model test. Odessa, FL: Psychological Assessment Resources.

Ekinci, Y, Hosany S. 2006. "Destination personality: An application of brand personality to tourism destinations." Journal of Travel Research 45 (2): 127-139.

Fuller, J. 2011. "Martial arts and psychological health: Psychology and Psychotherapy." British Journal of Medicine and Psychology 61 (4): 317-328.

Grucza, RA, Goldberg LR. 2007. "The comparative validity of 11 modern personality inventories: Predictions of behavioral acts, informant reports, and clinical indicators." Journal of Personality Assessment 89: 167-187.

Hill, DM, Hanton S, Matthews N, Fleming S. 2010. "Choking in sport: a review." International Review of Sport and Exercise Psychology 3 (1): 24-39.

Hirsh, JB, DeYoung CG, Peterson JB. 2009. "Metatraits of the Big Five differentially predict engagement and restraint of behavior." Journal of Personality 77: 1085-1102.

Ilyasi, G, Salehian MH. 2011. "Comparison of personality traits between individual and team athletes." Middle East Journal of Scientific Research 9 (4): 527-530.

John, OP, Robins RW, Pervin LA. 2008. Handbook of personality: Theory and research. New York: Guilford Press, 114-158.

Kajtna, T, Tusak M, Barić R, Burnik S. 2004. "Personality in high-risk sports athletes." Kinesiology 36 (1): 24-34.

McCrae, R, Costa Jr. P. 2003. Personality in Adulthood: A Five-Factor theory perspective. New York: Guilford Press.

McKelvie, SJ, Lemieux P, Stout D. 2003. "Ekstraversion and neuroticism in contact athletes, no contact athletes and nonathletes: a research note." Journal of Sport Psychology 5 (3): 19-27.

Mirzaei, A, Nikbakhsh R, Sharififar F. 2013. "The relationship between personality traits and sport performance." European Journal of Experimental Biology 3 (3): 439-442. 
Nielsen, RO. 2013. "Classifying running-related injuries based upon etiology with emphasis on volume and pace." International Journal of Sports Physical Therapy 8 (2): 172-179.

Paunonen, SV. 2003. "Big Five factors of personality and replicated predictions of behavior." Journal of Personality and Social Psychology 84: 411-424.

Piedmont, RL, Hill D, Blanco S. 1999. "Predicting athletic performance using the five factor model of personality." Personality and Individual Differences 27: 769-777.

Piepiora, P. 2015. "Reaktywność emocjonalna zawodników karate startujących w odmiennych systemach walki sportowej kumite.” Roczniki Naukowe Wyższej Szkoły Wychowania Fizycznego i Turystyki w Białymstoku 3(13): 46-51.

Piepiora, P., Cięszczyk I., Krzesiński M. 2017a. "Young athlete personality model using the example of selected sport disciplines.” Roczniki Naukowe Wyższej Szkoły Wychowania Fizycznego i Turystyki w Białymstoku 4 (22): 5-13.

Piepiora, P., Cięszczyk I., Krzesiński M. 2017b. "Wizerunek a agresywność młodych sportowców na przykładzie wybranych dyscyplin sportowych." Roczniki Naukowe Wyższej Szkoły Wychowania Fizycznego i Turystyki w Biatymstoku 1 (19): 45-51.

Piepiora, P., Cięszczyk I., Krzesiński M. 2018a. "Różnice w temperamencie wśród młodzieżowych zawodników trenujących sport indywidualny i zespołowy." Roczniki Naukowe Wyższej Szkoły Wychowania Fizycznego $i$ Turystyki w Biatymstoku 3 (25): 44-50.

Piepiora, P., Jagoda A., Urban J. 2019a. "Physical activity and styles of coping with the stress of people aged 18-30." Journal of Education, Health and Sport 9 (7): 36-40.

Piepiora, P., Kwieciński A., Migasiewicz J. 2019b. "The impact of the level of focus on a change in the level of fear of falling during leading in competition climbing." Journal of Education, Health and Sport 9 (5): 516-533.

Piepiora, P., Migasiewicz J., Napieraj D. 2019c. "Personality profile of athletes practising endurance disciplines." Journal of Education, Health and Sport 9 (4): 394-402.

Piepiora, P., Piepiora D., Witkowski K. 2016a. "Personality of the karatekas and kumite sport fight systems (in view of the karate culture as the regulator of this interdependence)." Journal of Combat Sports and Martial Arts 7(1): 35-41.

Piepiora, P., Piepiora Z. 2015. "The karate culture as the regulator of interdependence between permitted level of violence in different kumite systems and personality of contestants." Human And Social Sciences at the Common Conference (HASSACC) 3 (1): 23-27.

Piepiora, P., Superson M., Migasiewicz J. 2019d. "Personality and subjective assessment of body weight of tennis players." Journal of Education, Health and Sport 9 (6): 394-397.

Piepiora, P., Superson M., Witkowski K. 2017c. "Osobowość a masa ciała i poziom tkanki tłuszczowej na przykładzie zawodniczek piłki siatkowej." Roczniki Naukowe Wyższej Szkoły Wychowania Fizycznego i Turystyki w Biatymstoku 2 (20): 52-55.

Piepiora, P., Superson M., Witkowski K. 2017d. "Personality and the body composition of athletes using the example of the Polish national youth female wrestling team." Journal of Combat Sports and Martial Arts 8 (2): 107-109.

Piepiora, P., Superson M., Witkowski K. 2017e. "Personality and the nutritional habits of athletes using the example of the Polish national youth female wrestling team." Archives of Budo: Science of Martial Arts and Extreme Sports, 13" 103-110.

Piepiora, P., Supiński J., Witkowski K. 2015. "The temperament of karate competitors versus the systems of kumite sports fight." Journal of Combat Sports and Martial Arts 6 (2): 49-52.

Piepiora, P., Szmajke A., Migasiewicz J., Witkowski K. 2016b. "The karate culture and aggressiveness in kumite competitors." Ido: Movement for Culture: Journal of Martial Arts Anthropology 16 (2): 41-47.

Piepiora, P., Witkowski K. (2018). "Personality traits of competitive athletes according to type of pressure exerted on opponents." South African Journal for Research in Sport, Physical Education and Recreation 40 (1): 97-109;

Piepiora, P., Witkowski K., Piepiora Z. 2018b. "Personality profiles of karate masters practising different kumite styles." Archives of Budo 14: 231-241.

Shipley, BA, Weiss G, Der G, Taylor MD, Dearly IJ. 2007. "Neuroticism, extraversion and mortality in the UK Health and lifestyle survey: A 21-year prospective cohort study." Psychosomatic Medicine 69 (9): 923-931.

Shrivastaval, P, Gopal R, Singh Y. 2010. "A Study of Personality Dimensions in Sports Performance.” Journal of Exercise Science and Physiotherapy 1" 39-42.

Soto CJ, John OP, Gosling SD, Potter J. 2008. "The developmental psychometrics of Big Five self-reports: acquiescence, factor structure, coherence, and differentiation from ages 10 to 20. Journal of Personality and Social Psychology 94: 718-737.

Terracciano A, Schrack JA, Sutin AR, Chan W, Simonsick EM, Ferrucci L. 2013. "Personality, metabolic rate and aerobic capacity." Plos One 8 (1): 547-556.

Tok, S. 2013. "The Big Five personality traits and risky sport participation." Social Behaviour and Personalisty an International Journal 39: 1105-1012.

Tolea, MI, Terracciano A, Simonsick EM, Metter TJ, Costa Jr. P, Ferrucci L. 2012. 'Associations between personality traits, physical activity level and muscle strength." Journal of Research in Personality 46 (3): 264-270.

Tomczak, M, Bręczewski G, Sokołowski M, Kaiser A, Czerniak U. 2013. "Personality traits and stress coping styles in the Polish National Cadet Wrestling Team." Archives of Budo 2: 161-168.

Wiggins, J. 1996. The Five-Factor model of personality. New York: Guildford Press.

Zdebski, J, Blecharz J. 2004. “Looking for an optimum model of athlete's support.” Biology of Sport 21 (2): 129-137. 